[Agr. Biol. Chem., Vol. 31, No. 3, p. 330 335, 1967]

\title{
Studies on Bacterial Protease
}

\section{Part XVII. Some Physicochemical Properties and Amino Acid Composition of Alkaline Protease of Bacillus subtilis var. amylosacchariticus}

\author{
By Daisuke Tsuru, Heizo Kira, Takehiko Yamamoto and \\ Juichiro Fuкuмото \\ Faculty of Science, Osaka City University, Sumiyoshi-ku, Osaka \\ Received October 31, 1966
}

\begin{abstract}
Some physicochemical properties and amino acid composition of the alkaline protease of $B$. amylosacchariticus were determined. The molecular weight and sedimentation coefficient were estimated to be 22,700 and $2.89 \mathrm{~s}$, respectively, and the amino terminal amino acid was identified to be alanine. The enzyme contained $15.9 \%$ of nitrogen and was composed of 220 residues of amino acid: lys $_{6}$, his $_{5}, \arg _{3}$, asp $_{20}$, thr $_{14}$, ser $_{37}$, glu $_{12}$, pro $_{10}$, gly $_{25}$, ala $_{27}, \mathrm{val}_{20}, \mathrm{met}_{3}$, isoleu $12, \mathrm{leu}_{12}, \mathrm{ty}_{\mathrm{g}}, \mathrm{phe}_{2}, \operatorname{try}_{3}$ and amide ammonia $\mathrm{I}_{16}$. The results indicate that protein nature and chemical properties of the alkaline protease presented here are distinct from those of alkaline proteases obtained from the other strains of $B$. subtilis, such as subtilopeptidase $\mathrm{A}, \mathrm{B}$ and $\mathrm{BPN}$ '
\end{abstract}

\section{INTRODUCTION}

In the previous paper, " the authors reported the purification method and some enzymatic properties of the alkaline protease isolated from B. amylosacchariticus which was a strain of saccharifying $\alpha$-amylase-producing Bacillus subtilis. ${ }^{2,31}$ The protease showed properties almost similar to those of $B$. subtilis alkaline proteases ever reported such as $K_{13}$ protease," subtilopeptidase $\mathrm{A},{ }^{5 !} \mathrm{B},{ }^{6,7}$ and $\mathrm{BPN},{ }^{8 \sim 11) *}$ However,

1) D. Tsuru, H. Kira, T. Yamamoto and J. Fukumoto, This Journal, 30, 1261 (1966).

2) J. Fukumoto, T. Yamamoto and K. Ichikawa, Proc. Japan Acad., 27, 352 (1951).

3) J. Fukumoto and S. Okada, J. Ferm. Tech., 41, 427 (1963).

* Subtilopeptidase A and B were previously called subtilisin and nove enzyme, respectively. BPN' is commercially available under the trade name of nagarse.

4) J. Fukumoto, T. Y amamoto and K. Ichikawa, J. Agr. Chem. Soc. Japan, 33, 9 (1959).

5) A. V. Guntelburg and M. Ottesen, Compt. Rend. Trav. Lab. Carlsberg, 29, 36 (1954).

6) G.Johansen and M.Ottesen, ibid., 34, 199 (1964).

7) M. Ottesen and A. Spector, ibid., 33, 63 (1960). it was found that solubility in neutral solution of the purified preparation of $B$. amylosacchariticus alkaline protease was very low as compared with that of other B. subtilis proteases." The former enzyme was easily crystallized out during the dialysis against $2 \times 10^{-3} \mathrm{M}$ calcium acetate solution at $\mathrm{pH}$ values between 6.5 and 8.5, if the enzyme concentration was higher than $0.5 \%$.

The present investigation was undertaken to determine some physicochemical properties and amino acid composition of the alkaline protease of $B$. amylosacchariticus, comparing with those of $B$. subtilis alkaline proteases so

8) B. Hagihara, "The Enzymes," Vol. 4, Academic Press Inc., New York, (1958), p. 193.

9) H. Matsubara, B. Hagihara, M. Nakai, T. Komaki, T. Yonetani and K. Ohnuki, J. Biochem., 45, 251 (1958).

10) H. Matsubara, C. B. Kasper, D. M. Brown and E. L. Smith, J. Biol. Chem., 240, 1125 (1965).

11) C. B. Kasper, H. Matsubara and E. L. Smith, ibid., 240, 1135 (1965). 
far reported, in order to ascertain whether these enzymes were distinguishable in their protein chemical properties.

\section{MATERIALS AND METHODS}

The purification and assay methods of the alkaline protease of $B$. amylosacchariticus were described previouly." The enzyme preparations used in this experiment showed a specific activity (activity units per $\mathrm{mg}$ of protein) greater than 2200 , that indicated the purity of the preparations to be more than $95 \%$. Protein concentration was determined spectrophotometrically at $280 \mathrm{~m} \mu$ using the factor $\left.E_{1}^{1 \%} \mathrm{~cm}=11.9 .1\right)$

Element analysis. Determination of carbon, hydrogen and nitrogen contents of the enzyme was performed at Microanalysis Laboratory of our Institute and nitrogen was also analyzed by the semi-micro Kjeldahl method. Sulfur content was calculated from the data of amino acid analysis.

Ultracentrifugal and electrophoretic analyses. Ultracentrifugal analysis was carried out at Institute for Protein Research, Osaka University, using a Hitachi Analytical Ultracentrifuge UCA-I, as described previously.1,12) The sedimentation coefficient of the enzyme was calculated by the method described by Schachman, ${ }^{13}$ and was corrected to that at $20^{\circ}$ in water according to the method of Svedberg. ${ }^{14)}$ For the determination of molecular weight, approach to sedimentation equilibrium was adopted. The weight average molecular weight of the enzyme was calculated at the meniscus according to the method described by Schachman.13) Electrophoretic analysis was made using a Hitachi Tiselius Electrophoresis Apparatus HT-B at Department of Applied Biochemistry, Osaka Municipal Technical Research Institute. The lyophilized enzyme preparation was dissolved in $25 \mathrm{mM}$ buffer solution of various $\mathrm{pH}$ values, and, after adjusting the ionic strength to 0.1 with sodium chloride, the enzyme solution was dialyzed against a buffer solution of the same constituent in the cold and then subjected to the electrophoretic analysis. Partial specific volume was measured with a $5-\mathrm{ml}$ pycnometer at enzyme concentrations of 1.0 and $0.7 \%$ and at $30^{\circ}$. Amino terminal amino acid of the enzyme was

12) D. Tsuru, H. Kira, T. Yamamoto and J. Fukumoto, This Journal, 30, 1164 (1966).

13) H. K. Schachman, "Methods in Enzymology," IV, Academic Press Inc., New York, (1957), p. 32.

14) T. Svedberg and D. K. Pederson, "The Ultracentrifuge," Claredon Press Inc., Oxford (1940), p. 445. identified by the Sangers' DFB method with an inactivated enzyme preparation by TCA.12,15) The details of the experimental procedures were described in the previous paper. ${ }^{121}$

Determination of amino acid composition was kindly carried out at Shionogi Research Laboratory, Shionogi \& Co., Ltd., with a Hitachi Automatic Amino Acid Analyzer. The crystalline enzyme preparation lyophilized was dissolved in a minimum volume of water and precipitated by the addition of acetone to a final concentration of $67 \%(\mathrm{v} / \mathrm{v})$ in the cold. The protein was collected by centrifugation, washed twice with $80 \%$ acetone, successively once with acetone and ether, and then dried at $100^{\circ} \mathrm{C}$ in vacuo to a constant weight.

\section{RESULTS AND DISCUSSION}

\section{1) Physical and Chemical Properties.}

Sedimentation coefficient and molecular weight of the enzyme. The sedimentation coefficient, $S_{20, w}$ was calculated from the sedimentation velocity run shown in Fig. 1-A, and a value of $2.89 \times 10^{-13}$ was obtained. The analysis was operated at 55,100 r.p.m. and $18.4^{\circ}$ in a standard $12 \mathrm{~mm}, 4^{\circ}$ sector cell with 0.68 to $0.39 \%$ enzyme solution. In Fig. 1-B, approach to sedimentation equilibrium run is shown. The experimental conditions were almost the same as those described above with the exception that $13,100 \mathrm{r} . \mathrm{p} . \mathrm{m}$. was chosen. The concentration of the original sample was determined in arbitrary units in a $12 \mathrm{~mm}, 4^{\circ}$ sector synthetic boundary cell. The apparent molecular weight was calculated for each photograph at meniscus and the values were plotted against time (Fig. 2). The time dependence of molecular weight with a positive slope was observed and the molecular weight, 22,700 , was obtained by extrapolating the apparent molecular weight to zero time by the least squares method.

Amino terminal amino acid. The TCA-inactivated enzyme was used for the identification of the amino terminal amino acid. By the method described in the previous paper, ${ }^{121}$ a

15) D. Tsuru, J. D. McConn and K. T. Yasunobu, J. Biol. Chem., 240, 2415 (1965). 


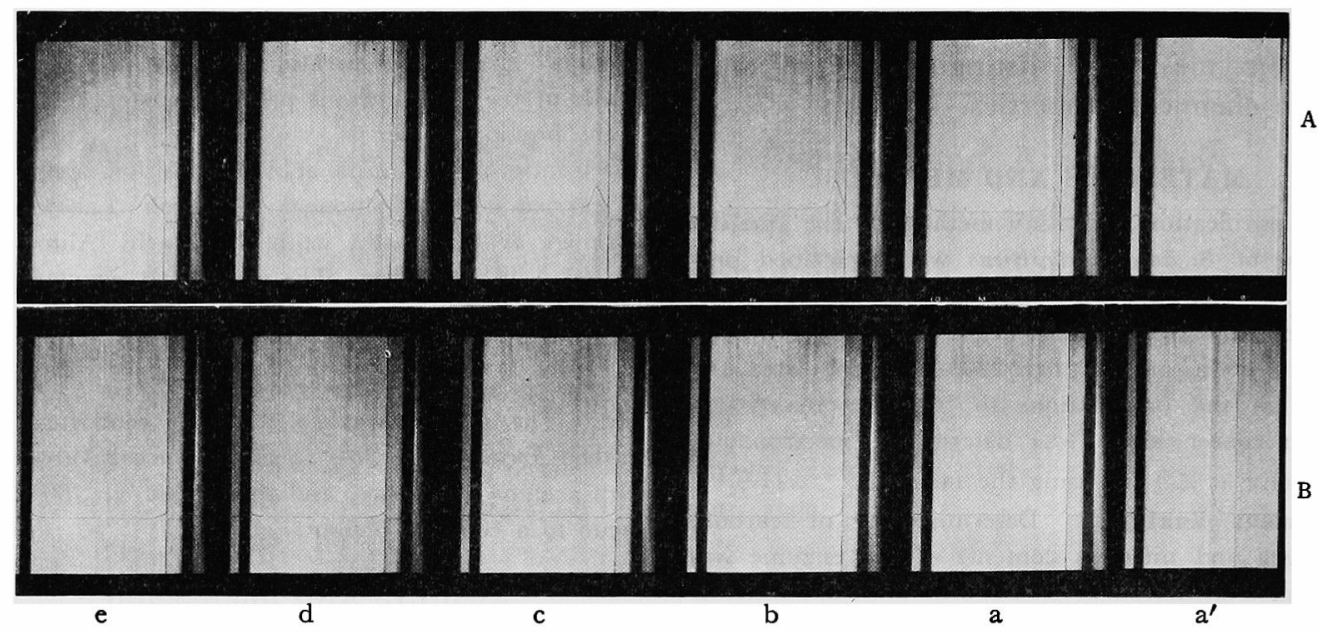

FIG. 1. Ultracentrifuge Pattern and Archibald Run of Alkaline Protease of B. amylosacchariticus

A: The sedimentation velocity run. The photographs were taken from right to left at 7 , $18,33,43,53$ and 60 minutes after reaching the full speed, 55,100 r.p.m. The enzyme concentration used was $0.68 \%$ in $0.01 \mathrm{M}$ acetate buffer, $\mathrm{pH} 5.8$, containing sodium chloride to adjust the ionic strength to 0.1 .

B: Archibald run. The photographs were taken at 15(a), 25(b), 35(c), 45(d) and 55 minutes (e) after reaching the full speed, 13,100 r.p.m. a' indicates a synthetic boundary run performed under the same condition as in $b$.

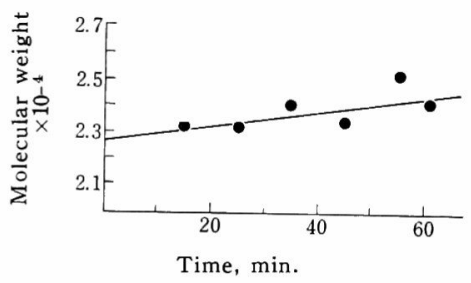

FIG. 2. Variation of Apparent Molecular Weight with Time in Archibald Run. 1-B.

The experimental conditions are described in Fig.

considerable quantity of alanine together with a trace amount of aspartic acid were found as dinitrophenylated amino acids. Quantitative analysis indicated that 0.6 to 0.7 moles of DNP-alanine were recovered per mole of enzyme on the basis of molecular weight of 22,700 while the quantity of DNP-aspartic acid obtained was stoichiometrically negligible.

Partial specific volume. Duplicate determinations of partial specific volume of the enzyme yielded a value of 0.72 .

Using the values obtained for molecular weight, $S_{20, w}$, and partial specific volume, the frictional ratio, $f / f_{0}$, of the enzyme was computed to be 1.04 .

In Table I physical and chemical properties of the alkaline protease of $B$. amylosacchariticus are summarized and compared with those of $B$. subtilis alkaline proteases so far reported. Table I shows that all these alkaline proteases are possessed of alanine as the amino terminal amino acid. However, there can be seen a considerable difference in the molecular weight between $B$. amylosacchariticus alkaline protease and the other three enzymes.

\section{2) Amino Acid Composition.}

In Table II, amino acid composition of $B$. amylosacchariticus alkaline protease is presented. The amino acid analysis was carried out with the samples hydrolyzed for 24, 48 and 72 hours. The values for threonine, serine and amide ammonia were those obtained by extrapolating 
Tabl I. Some Physical and Chemical Properties of Alkaline Proteases OBTAINED FROM VARIOUS STRAINS OF B: subtilis

\begin{tabular}{cccc}
$\begin{array}{c}\text { B. amylosach. } \\
\text { protease }\end{array}$ & \multicolumn{2}{c}{ Subtilopeptidase ${ }^{5 \sim 8}$} & BPN'10 $^{\prime}$ \\
11.9 & 8.6 & - & 11.7 \\
11.6 & 7.1 & 11.0 & 9.7 \\
2.89 & 2.85 & 2.7 & 2.77 \\
0.72 & 0.749 & - & - \\
0.725 & - & - & 0.73 \\
$7.5 \sim 8.0$ & 9.4 & 9.1 & 7.8 \\
22.7 & 30 & 28 & 27.7 \\
1.04 & 1.14 & - & 1.18 \\
2.3 & - & 2.2 & 2.2 \\
Alanine & Alanine & Alanine & Alanine \\
50.86 & - & - & 49.5 \\
7.18 & - & - & 7.5 \\
0.44 & - & - & 0.76 \\
15.9 & 16.6 & 16.4 & 16.88 \\
1.3 & - & - & 1.3
\end{tabular}

$E_{280 \mathrm{~m} \mu}^{1 \%}\left\{\begin{array}{l}\text { observed } \\ \text { calculated* }\end{array}\right.$
$S_{20, w}$
$\bar{V}\left\{\begin{array}{l}\text { experimental } \\ \text { calculated* }\end{array}\right.$
Isoelectric point
Molecular weight $\times 10^{-3}$
$f / f_{0}$
Specific activity (units $/ \mathrm{m} s$

Amino terminal amino acid

C, \%

$\mathrm{H}, \%$

$\mathrm{S}, \%$

$\mathrm{N}, \%$

Ash, $\%$

* Calculated from the amino acid composition shown in Tables II and III and References 6 and 10 .

Table II. Amino Acid Composition of Alkaline Protease of B. amylosacchariticus

Amino acid

\begin{tabular}{|c|c|}
\hline Lysine & $\begin{array}{c}\% \\
3.62 b\end{array}$ \\
\hline Histidine & $3.19 \mathrm{~b})$ \\
\hline Arginine & $2.15^{b)}$ \\
\hline Aspartic acid & $12.04^{b)}$ \\
\hline Threonine & $7.21 \mathrm{c})$ \\
\hline Serine & $17.21^{\mathrm{c})}$ \\
\hline Glutamic acid & $7.64 b)$ \\
\hline Proline & $4.83^{b l}$ \\
\hline Glycine & $8.16^{\mathrm{b})}$ \\
\hline Alanine & $10.56^{b}$ \\
\hline Half cystine & 0 \\
\hline Valine & $10.24^{d)}$ \\
\hline Methionine & $2.04 \mathrm{~d})$ \\
\hline Isoleucine & $7.05^{d)}$ \\
\hline Leucine & $6.99 \mathrm{~b})$ \\
\hline Tyrosine & $7.33 b 1$ \\
\hline Phenylalanine & $\left.1.66^{b}\right)$ \\
\hline Tryptophan & $2.40^{\prime \prime}$ \\
\hline Amide- $\mathrm{NH}_{2}$ & $(1.20)^{\circ}$ \\
\hline
\end{tabular}

Amino acid residue

9
3.18
2.82
1.92
10.41
6.13
14.26
6.70
4.07
6.20
8.42
0
8.66
1.79
6.08
6.03
6.60
1.48
2.18
$(1.13)$
96.93

Nitrogen

$\begin{array}{ccc}\% & \text { Calculated } & \text { Integral } \\ 0.694 & 5.6 & 6 \\ 0.863 & 4.7 & 5 \\ 0.690 & 2.8 & 3 \\ 1.270 & 20.4 & 20 \\ 0.851 & 13.7 & 14 \\ 2.294 & 37.0 & 37 \\ 0.724 & 11.7 & 12 \\ 0.589 & 9.5 & 10 \\ 1.522 & 24.6 & 25 \\ 1.660 & 26.8 & 27 \\ - & - & - \\ 1.230 & 19.8 & 20 \\ 0.191 & 3.1 & 3 \\ 0.755 & 12.1 & 12 \\ 0.747 & 12.0 & 12 \\ 0.567 & 9.2 & 9 \\ 0.140 & 2.3 & 2 \\ 0.327 & 2.7 & 3 \\ 0.989 & (16) & (16) \\ 16.10 & & 220\end{array}$
a) Based on a molecular weight of 22,700 .
b) Average values from 24,48 and 72 hour hydrolyzates.
c) Values extrapolated to zero hydrolysis time.
d) Maximum values adopted.
e) Calculated from ultraviolet absorption. 
to zero hydrolysis time. For valine, methionine and isoleucine, the maximum values obtained from 72 hour hydrolyzate were adopted. Analysis on the oxidized preparation by performic acid revealed that the enzyme contained no half cystine. Tryptophan content was calculated from the ultraviolet absorption of the enzyme dissolved in $0.1 \mathrm{~N}$ sodium hydroxide solution ${ }^{16)}$ (Fig. 3). The tyrosine content calculated from Fig. 3 was in good

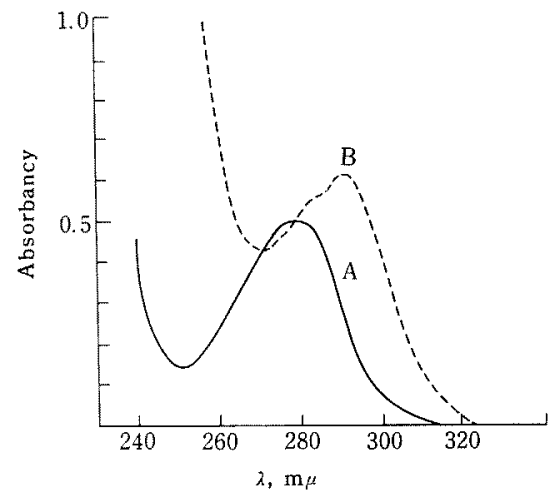

FIG. 3. Ultraviolet Absorption Spectra of B. amylosacchariticus Alkaline Protease.

The enzyme concentration was $413 \mu \mathrm{g} / \mathrm{ml}$.

A: In $10^{-2} \mathrm{M}$ Tris- $\mathrm{HCl}$ buffer, $\mathrm{pH} 7.3$.

B: In $10^{-1} \mathrm{M} \mathrm{NaOH}$ solution.

agreement with that obtained from the analysis by an amino acid analyzer. The absorption spectrum of the enzyme in neutral solution revealed a maximum at $278 \mathrm{~m} \mu$ and the ratio of absorption at 280 to $260 \mathrm{~m} \mu$ was 2.1 , indicating the absence of significant amounts of nucleic acid component.

The sum of total residues of amino acids accounted for about $97 \%$ of the dried enzyme preparation, whereas the recovery of nitrogen was shown to exceed $100 \%$. The remaining $3 \%$ might be impurities such as ash and nonnitrogenous compounds. Element analysis indicated that the crystalline preparation con-

16) T.W. Goodwin and R. A. Morton, Biochem. J., 40, 628 (1946). tained $1.3 \%$ of ash. Using the value of 22,700 for the molecular weight, the enzyme was found to be composed of 220 residues of amino acids. The partial specific volume and absorbancy at $280 \mathrm{~m} \mu$ computed from the amino acid composition were 0.725 and 11.6 , respectively.

In Table III, the amino acid composition of

TABLE III. COMPaRISON OF AMINo Acrd CoMposItion of Alkaline Proteases Obtained FROM VARIOUS STRAINS OF B. subtilis

Moles amino acid $/ 10^{5} \mathrm{~g}$ of protein

B. amylosacch. Subtilopepti- BPN'10) protease dase $^{6}$

Lysine

Histidine

Arginine

Aspartic acid

Threonine

Serine

Proline

Glutamic acid

27
23
14
91
64
168
45
55
114
123
0
91
13
55
55
41
9
14
73

$\begin{array}{rrr}\text { A } & \text { B } & \\ 31 & 39 & 39 \\ 17 & 21 & 21 \\ 14 & 7 & 7 \\ 106 & 103 & 100 \\ 68 & 46 & 50 \\ 126 & 135 & 136 \\ 31 & 53 & 50 \\ 41 & 53 & 57 \\ 133 & 120 & 121 \\ 147 & 135 & 135 \\ 0 & 0 & 0 \\ 120 & 110 & 107 \\ 20 & 18 & 18 \\ 38 & 46 & 46 \\ 58 & 53 & 54 \\ 44 & 35 & 36 \\ 14 & 11 & 11 \\ 4 & 14 & 11 \\ 96 & 103 & 100\end{array}$

the proteases obtained from several strains of $B$. subtilis is compared with that of B. amylosacchariticus alkaline protease. For the sake of convenience, nearest integral numbers of amino acid residues per 100,000 grams of protein are presented.

It is most likely that subtilopeptidase B and BPN' are the same since they are quite similar not only in their enzymatic properties but also in their amino acid composition, as has been suggested by Johansen and Ottesen ${ }^{6 /}$ and Matsubara et al. ${ }^{101}$ The alkaline protease of 
B. amylosacchariticus also showed enzymatically similar properties with those of subtilopeptidase $\mathrm{B}\left(\mathrm{BPN}^{\prime}\right)$. However, solubility in neutral solution $^{1 /}$ and molecular weight of both enzymes were somewhat different each other. More appreciable difference between the two proteases was in their amino acid composition, especially in the content of lysine, arginine, threonine, serine, methionine, valine, isoleucine and tyrosine. The results indicate that the alkaline protease of $B$. amylosacchariticus is distinguished in the protein chemical nature from the other $B$. subtilis proteases so far reported, suggesting the existence of diversity in alkaline proteases of $B$. subtilis group.

Acknowledgements. The authors wish to express their gratitude to Dr. M. Ebata of Shionogi Research Laboratory, Shionogi \& Co., Ltd., for the performance of amino acid analysis. Thanks are also due to Dr. K. Kakiuchi of Institute for Protein Research, Osaka University, and to Dr. Y. Tsujisaka of Osaka Municipal Technical Research Institute for their courtesy on ultracentrifugal and electrophoretic analyses. 